WWW.ijbpas.com

\title{
VITAMIN D STATUS IN PREGNANT WOMEN AND ITS ASSOCIATION WITH PREGNANCY OUTCOMES
}

\author{
SHAH BM ${ }^{* 1}$ AND PATIL SK ${ }^{2}$ \\ 1: Department of Obstetrics \& Gynecology, Krishna Institute of Medical Sciences, Karad \\ 2: Department of Obstetrics \& Gynecology, Krishna Institute of Medical Sciences, Karad
}

*Corresponding Author: Dr. Bela Milind Shah: E Mail: bela.shah63@gmail.com

Received $15^{\text {th }}$ July 2021; Revised $18^{\text {th }}$ Aug. 2021; Accepted $29^{\text {th }}$ Oct. 2021; Available online $15^{\text {th }}$ Feb. 2022

https://doi.org/10.31032/IJBPAS/2022/11.2.1038

\begin{abstract}
This study was aimed to determine the vitamin D status in pregnant women attending a tertiary care hospital and its association with pregnancy outcomes and to determine the correlation between maternal and cord blood vitamin D levels. Three hundred \& sixty consecutive primigravidae with singleton pregnancy admitted to the labour ward of a tertiary care centre were recruited for the study. Women with type $1 \mathrm{DM}$, malabsorption, hepatic/renal/adrenal diseases, overt thyroid/parathyroid diseases, metabolic bone diseases and women not willing to participate were excluded from the study. Maternal and cord blood samples were taken and analyzed for $25(\mathrm{OH}) \mathrm{D}$ level. Maternal outcomes and cord blood levels were studied. High prevalence of hypovitaminosis D was found among pregnant women. $57.8 \%$ women had insufficiency, $24.4 \%$ had deficiency and only $17.8 \%$ women had sufficient levels of vitamin D. Abnormal pregnancy outcome was noted in the form of antenatal complications like preeclampsia, gestational hypertension, eclampsia, GDM and PROM. Ladies with strange pregnancy results had genuinely huge nutrient D inadequacy and deficiency when contrasted with ladies with typical result $(\mathrm{p}=0.001)$. Mean vitamin $\mathrm{D}$ levels among women with preeclampsia, gestational hypertension, eclampsia, GDM and PROM were $14.3 \mathrm{ng} / \mathrm{ml}, 17.1 \mathrm{ng} / \mathrm{ml}, 16.4 \mathrm{ng} / \mathrm{ml}, 22.7$ $\mathrm{ng} / \mathrm{ml}, 20.6 \mathrm{ng} / \mathrm{ml}, 24.3 \mathrm{ng} / \mathrm{ml}$ respectively which were significantly low as compared to $34.2 \mathrm{ng} / \mathrm{ml}$ in women with normal outcome $(\mathrm{p}=0.001)$. Cord blood vitamin D levels strongly correlated with maternal vitamin $\mathrm{D}$ levels $(\mathrm{p}=0.001$ ). This examination showed an exceptionally high predominance of hypovitaminosis D among pregnant ladies and magnificent connection among's maternal and fetal nutrient D levels. Toxemia was the most well-known antenatal confusion in this examination.
\end{abstract}

Keywords: Gestational hypertension; Hypovitaminosis D; Preeclampsia; Pregnancy outcomes 


\section{INTRODUCTION}

Vitamin D is a fat-soluble vitamin which includes both animal-derived cholecalciferol (vitamin D3) and plant-derived ergocalciferol (vitamin D2). For decades, vitamin D is seen as "the bone vitamin" because of its major function, also called the classic function, in controlling calcium and bone homeostasis. Extreme nutrient D insufficiency causes rickets in youngsters or osteomalacia in grown-ups and perhaps adds to osteoporosis. Additionally, in the last few years, many other so-called non classic functions of vitamin $\mathrm{D}$ have been identified and through these mechanisms vitamin D insufficiency has been linked to an increased risk of a large number of diseases. $1,25(\mathrm{OH})_{2} \mathrm{D}$ has been shown to be capable of regulating cell differentiation and proliferation, as well as regulating immune function and hormone secretion. Associated health problems are thought to include cardiovascular diseases, immune disorders and several cancers demonstrating a variety of possible effects of vitamin $\mathrm{D}$ on human health. Surprisingly, vitamin D deficiency is worldwide spread among general populations. Studies carried across different countries in Asia showed widespread prevalence of hypovitaminosis $\mathrm{D}$ in different populations (Arya et al., 2004). Nutrient D inadequacy prompts critical medical conditions, in moms as well as in their newborn children, in light of the fact that the nutrient $\mathrm{D}$ store of the mother is the significant wellspring of nutrient $\mathrm{D}$ for the embryo. The vitamin D dose that the World Health Organization recommends for pregnant women is $200 \mathrm{IU} /$ day (WHO Guideline., 2012). The Institute of Medicine suggested that the "Estimated Average Requirement" and "Recommended Dietary Allowance" (RDA) for pregnant women be 400 and 600 IU/day, respectively. Late investigations announced that the day by day portion for pregnant ladies ought to be more prominent than $1000 \mathrm{IU} /$ day to accomplish sufficient levels (Mulligan et al., 2010). The security portion during pregnancy isn't clear, yet Hollis et al., 2011 showed that nutrient D supplementation of 4000 IU/day for accomplishing satisfactory levels was protected and powerful in pregnant ladies. The International Association of Endocrinology characterized a nutrient D degree of 21-29 $\mathrm{ng} / \mathrm{mL}$ as inadequacy and $<20 \mathrm{ng} / \mathrm{mL}$ as insufficiency in grown-ups (Holick MF et al., 2011). However, the levels of vitamin D insufficiency and deficiency are not clearly defined and the discussion about the prevalence of vitamin $\mathrm{D}$ deficiency is ongoing. The recommended value for serum vitamin $\mathrm{D}$ level is lower in children than adults. The Endocrine Society recommends nutrient $\mathrm{D}$ degrees of $>20$ 
$\mathrm{ng} / \mathrm{mL}$ for adequacy, $12-20 \mathrm{ng} / \mathrm{mL}$ for inadequacy and $<12 \mathrm{ng} / \mathrm{ml}$ as nutrient $\mathrm{D}$ insufficiency (Munns CF et al., 2016).

During pregnancy, it is more critical to ensure vitamin D adequacy for the health of both mother and offspring. Nutrient D lack during pregnancy has been related with expanded danger for strange pregnancy results, including toxemia, gestational diabetes mellitus, eclampsia, gestational diabetes mellitus, PROM, lower birth weight and hindered bone turn of events (Thorne-Lyman et al., 2012).As the studies regarding the prevalence of hypovitaminosis D in pregnancy and its correlation with pregnancy outcome are very sparse from India, this study was carried out to determine the vitamin D status in pregnant women attending a tertiary care hospital what's more, its relationship with pregnancy results and to decide the connection among's maternal and line blood nutrient $\mathrm{D}$ levels.

\section{RESULTS AND DISCUSSION}

In the present study figure no 1, it was observed that out of 360 enrolled women, $64(17.8 \%)$ cases had sufficient $(>32$ $\mathrm{ng} / \mathrm{ml})$ vitamin D level, 208 (57.8\%) cases had insufficient $(<32 \mathrm{ng} / \mathrm{ml})$ vitamin D level and 88 (24.4\%) cases had deficient $(<20 \mathrm{ng} / \mathrm{ml})$ vitamin D levels. The mean vitamin D level in sufficient $(>32 \mathrm{ng} / \mathrm{ml})$ group was $45.8 \pm 12.62 \mathrm{ng} / \mathrm{ml}$, in insufficient $(<32 \mathrm{ng} / \mathrm{mL})$ group was $24.6 \pm$
$4.16 \mathrm{ng} / \mathrm{ml}$ and in deficient $(<20 \mathrm{ng} / \mathrm{ml})$ group was $15.8 \pm 4.34 \mathrm{ng} / \mathrm{ml}$.

In the study conducted by Saloni Arora et al., (2017), it was observed that $4.5 \%$ cases had sufficient vitamin D level, 9.5\% cases had insufficient vitamin D level and 86.0\% cases had deficient vitamin $\mathrm{D}$ levels. In a similar study conducted by Nalini Sharma et al., (2019), it was observed that 3.4\% cases had sufficient vitamin D level, 12.4\% cases had insufficient vitamin D level and $84.2 \%$ cases had deficient vitamin D levels. Mean Vitamin D level in insufficient group was $24 \mathrm{ng} / \mathrm{ml}$ and mean vitamin D level in deficient group was $12 \mathrm{ng} / \mathrm{ml}$.

In women with sufficient vitamin D levels, $60(93.8 \%)$ cases had sufficient vitamin D level in cord blood, $3(4.7 \%)$ cases had insufficient vitamin D level in cord blood and only $1(1.1 \%)$ case had deficient vitamin D level in cord blood. Among the insufficient maternal vitamin D group, 7 (3.4\%) cases had sufficient vitamin D level in cord blood, 198 (95.2\%) cases had insufficient vitamin D level in cord blood and $3(1.4 \%)$ cases had deficient vitamin D level in cord blood. Among the deficient vitamin $\mathrm{D}$ level in maternal blood group, only $1(1.1 \%)$ case had sufficient vitamin D level in cord blood, $6(6.4 \%)$ cases had insufficient vitamin D level in cord blood and $81(92.6 \%)$ cases had deficient cord blood vitamin D level. Significant correlation was seen between vitamin D 
levels in mothers and vitamin $\mathrm{D}$ levels in cord blood of their newborns $(p=0.001)$

\section{(Table 1).}

In the study conducted Saloni Arora et al., (2017), similar correlation was found. Among the deficient maternal vitamin D level group, $2.3 \%$ cases had insufficient Vitamin D level in cord blood and 97.7\% cases had deficient Vitamin D level in cord blood.

In this study, 226(62.8\%) cases had normal pregnancy outcome, $52(14.4 \%)$ cases had preeclampsia, $3(0.8 \%)$ cases had eclampsia, $40 \quad(11.1 \%)$ cases had gestational hypertension, $36(10.0 \%)$ cases had PROM, 21 (5.8\%) cases had GDM and $2(0.6 \%)$ cases had IUGR (Figure 2).
It was observed mean vitamin $\mathrm{D}$ level in normal pregnancy outcome group was 34.2 $\pm 14.8 \mathrm{ng} / \mathrm{ml}$ and mean vitamin $\mathrm{D}$ level in abnormal pregnancy outcome group was $18.6 \pm 12.5 \mathrm{ng} / \mathrm{ml}$ which was statistically significant ( $\mathrm{p}=0.001)$ (Table 2).

Mean vitamin D level in preeclampsia cases was $14.3 \pm 5.3 \mathrm{ng} / \mathrm{ml}$, in eclampsia cases was $16.4 \pm 6.2 \mathrm{ng} / \mathrm{ml}$, in Gestational HTN cases was $17.1 \pm 8.3 \mathrm{ng} / \mathrm{ml}$, in PROM was $20.6 \pm 6.7 \mathrm{ng} / \mathrm{ml}$, in Gestational DM was $22.7 \pm 7.8 \mathrm{ng} / \mathrm{ml}$ and in IUGR was $24.3 \pm 4.0 \mathrm{ng} / \mathrm{ml}(\mathrm{p}=0.001)$. In the study conducted by Nalini Sharma et al., (2019), it was observed that mean vitamin $D$ level in normal pregnancy outcome group was $16.02 \mathrm{ng} / \mathrm{ml}$, in PIH group was $13.52 \mathrm{ng} / \mathrm{ml}$

(Table 3, 4).

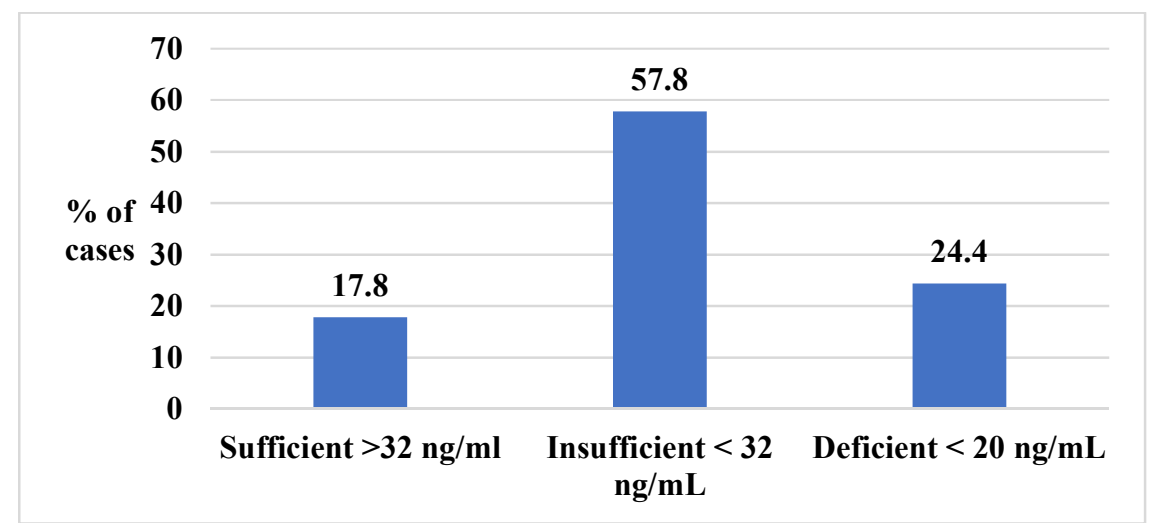

Figure 1: Distribution of cases according to Vitamin D level in Maternal blood

Table 1: Comparison of Vitamin D level in maternal blood with Cord blood

\begin{tabular}{|c|c|c|c|c|}
\hline \multirow{2}{*}{$\begin{array}{l}\text { Vitamin D level } \\
\text { (Mother) }\end{array}$} & \multicolumn{3}{|c|}{ Vitamin D level (Cord blood) } & \multirow[t]{2}{*}{ Total } \\
\hline & Sufficient $>32 \mathrm{ng} / \mathrm{ml}$ & $\begin{array}{c}\text { Insufficient }<32 \\
\mathrm{ng} / \mathrm{mL}\end{array}$ & $\begin{array}{c}\text { Deficient }<20 \\
n g / m L\end{array}$ & \\
\hline Sufficient $>32 \mathrm{ng} / \mathrm{ml}$ & $60(93.8 \%)$ & $3(4.7 \%)$ & $1(1.1 \%)$ & $64(100.0 \%)$ \\
\hline Insufficient $<32 \mathrm{ng} / \mathrm{mL}$ & $7(3.4 \%)$ & $198(95.2 \%)$ & $3(1.4 \%)$ & $208(100.0 \%)$ \\
\hline Deficient $<20 \mathrm{ng} / \mathrm{mL}$ & $1(1.1 \%)$ & $6(6.4 \%)$ & $81(92.6 \%)$ & $88(100.0 \%)$ \\
\hline Total & $68(18.9 \%)$ & $207(57.5 \%)$ & $85(23.6 \%)$ & $360(100.0 \%)$ \\
\hline
\end{tabular}

$P$ value 0.001 (Chi square test) 


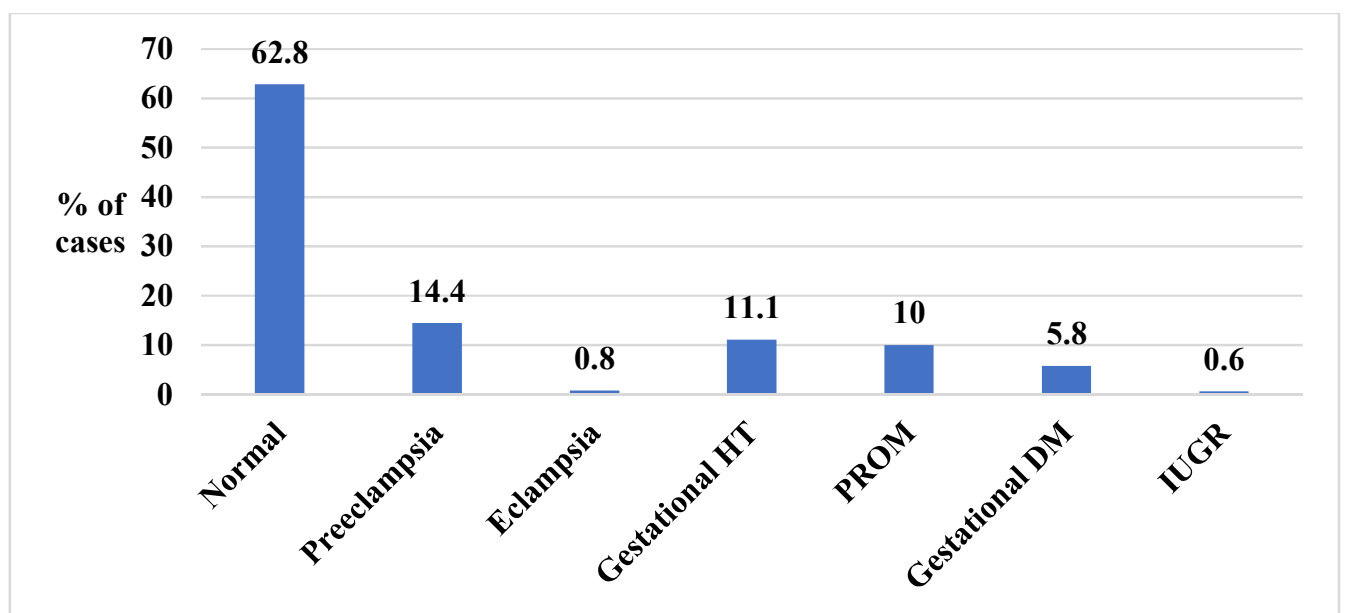

Figure 2: Distribution of cases according to Pregnancy outcome

Table 2: Mean distribution of Vitamin D level according to pregnancy outcome at term

\begin{tabular}{|c|c|c|}
\hline Vitamin D level & Mean & SD \\
\hline Normal outcome & 34.2 & 14.8 \\
\hline Abnormal pregnancy outcome & 18.6 & 12.5 \\
\hline
\end{tabular}

$P$ value 0.001 ( $T$ test)

Table 3: Mean distribution of Vitamin D level according to pregnancy outcome

\begin{tabular}{|c|c|c|c|}
\hline Pregnancy outcome & Mean & SD & P value* \\
\hline Normal & 34.2 & 14.8 & - \\
\hline Preeclampsia & 14.3 & 5.3 & 0.001 \\
\hline Eclampsia & 16.4 & 6.2 & 0.001 \\
\hline Gestational HT & 17.1 & 8.3 & 0.001 \\
\hline PROM & 20.6 & 6.7 & 0.001 \\
\hline Gestational DM & 22.7 & 7.8 & $\mathbf{0 . 0 0 1}$ \\
\hline IUGR & 24.3 & 4.0 & $\mathbf{0 . 0 0 1}$ \\
\hline
\end{tabular}

*Mean are compared with normal outcome cases

Table 4: Distribution of cases according to Vitamin $D$ level in various outcomes at term

\begin{tabular}{|c|c|c|c|c|}
\hline Outcome at term & Sufficient $>32 \mathrm{ng} / \mathrm{ml}$ & Insufficient $<32 \mathrm{ng} / \mathrm{mL}$ & Deficient $<20 \mathrm{ng} / \mathrm{mL}$ & Total \\
\hline Normal & $75(33.2 \%)$ & $131(58.0 \%)$ & $20(8.8 \%)$ & 226 \\
\hline GDM & $6(28.6 \%)$ & $11(52.4 \%)$ & $4(19.0 \%)$ & 21 \\
\hline Preeclampsia & $3(5.8 \%)$ & $23(44.2 \%)$ & $26(50.0 \%)$ & 52 \\
\hline Gestational HTN & $3(7.5 \%)$ & $15(37.5 \%)$ & $22(55.0 \%)$ & 40 \\
\hline Eclampsia & $\mathbf{0}$ & $2(66.7 \%)$ & $1(33.3 \%)$ & $\mathbf{0 3}$ \\
\hline PROM & $7(19.4 \%)$ & $22(61.2 \%)$ & $7(19.4 \%)$ & 36 \\
\hline
\end{tabular}

\section{CONCLUSION}

This examination showed a high predominance of hypovitaminosis D among pregnant ladies and magnificent connection among's maternal and string blood nutrient D levels. More than 57\% mothers had insufficient vitamin D level and more than $24 \%$ mothers had deficient vitamin D level.
Vitamin D level in sufficient amount was observed in only $18 \%$ of the mothers. The most common antenatal complication observed was preeclampsia which was followed by gestational hypertension and PROM. This study suggests that efforts should be done to improve the Vitamin D level in pregnant mothers. It may reduce 
the common maternal complications like Hypertensive Disorders in Pregnancy, GDM and PROM. Vitamin D supplementation can be in the form of tablets, granules or syrup.

\section{DISCUSSION}

This was a prospective observational study conducted in a tertiary care center from October 2018 to August 2020. 360 full term primigravidae with singleton pregnancy who were admitted for delivery were recruited in this study. Pregnant women with type 1 DM, malabsorption, hepatic/renal/adrenal diseases, overt thyroid/parathyroid diseases, metabolic bone diseases and women not willing to participate were excluded from the study. Definite history was recorded from the enrolled pregnant ladies including total segment subtleties, dietary history, past clinical history, past obstetric history, antenatal history including subtleties of any antenatal difficulties, admission of nutrient D D tablets during pregnancy, its dose and duration. Maternal \& cord blood samples ( 5 $\mathrm{ml}$ each) were drawn from all the recruited patients at the time of delivery for estimation of $25(\mathrm{OH})$ D level. Outcome of pregnancy was seen in the form of antenatal complications like preeclampsia, gestational hypertension, eclampsia, GDM \& PROM. Data management and analysis was done using Microsoft Excel and Epi-

info software. The downright factors were surveyed utilizing Pearson chi-square test. The test was viewed as critical just if the $p$ esteem comes out to be under 0.05 . The quantitative factors were surveyed utilizing understudy $\mathrm{T}$ test. Maternal vitamin $\mathrm{D}$ level in normal outcome was compared to other outcomes with the help of T test.

\section{Acknowledgment}

The researchers would like to thank the Research all the participants who participated and supported this study.

\section{Funding}

This research did not receive any specific grant from funding agencies in the public, commercial, or not-for-profit sectors.

\section{Authors' contributions}

All authors contributed toward data analysis, drafting and revising the paper and agreed to be responsible for all the aspects of this work.

\section{Conflict of Interest}

We have no conflicts of interest to disclose.

\section{REFERENCES}

[1] Arora, S., Goel, P., Chawla, D., Huria, A. and Arya, A., 2018. Vitamin D status in mothers and their newborns and its association with pregnancy outcomes: Experience from a tertiary care center in Northern India. The Journal of Obstetrics and 
Gynecology of India, 68(5), pp.389393.

[2] Sharma, N., Nath, C. and Mohammad, J., 2019. Vitamin D status in pregnant women visiting a tertiary care center of North Eastern India. Journal of family medicine and primary care, 8(2), p.356.

[3] Maghbooli, Z., Hossein-Nezhad, A., Shafaei, A.R., Karimi, F., Madani, F.S. and Larijani, B., 2007. Vitamin D status in mothers and their newborns in Iran. BMC pregnancy and childbirth, 7(1), pp.1-6.

[4] Zhou, J., Su, L., Liu, M., Liu, Y., Cao, X., Wang, Z. and Xiao, H., 2014. Associations between 25hydroxyvitamin D levels and pregnancy outcomes: a prospective observational study in southern China. European journal of clinical nutrition, 68(8), pp.925-930.

[5] Holick, M.F., 2006, March. High prevalence of vitamin D inadequacy and implications for health. In Mayo Clinic Proceedings (Vol. 81, No. 3, pp. 353-373). Elsevier.

[6] Arya, V., Bhambri, R., Godbole, M.M. and Mithal, A., 2004. Vitamin D status and its relationship with bone mineral density in healthy Asian
Indians. Osteoporosis

international, 15(1), pp.56-61.

[7] Mulligan, M.L., Felton, S.K., Riek, A.E. and Bernal-Mizrachi, C., 2010. Implications of vitamin D deficiency in pregnancy and lactation. American journal of obstetrics and gynecology, 202(5), pp.429-e1.

[8] Munns, C.F., Shaw, N., Kiely, M., Specker, B.L., Thacher, T.D., Ozono, K., Michigami, T., Tiosano, D., Mughal, M.Z., Mäkitie, O. and Ramos-Abad, L., 2016. Global consensus recommendations on prevention and management of nutritional rickets. Hormone research in paediatrics, 85(2), pp.83-106.

[9] Thorne-Lyman, A.L. and Fawzi, W.W., 2012. Vitamin A and carotenoids during pregnancy and maternal, neonatal and infant health outcomes: a systematic review and meta-analysis. Paediatric and perinatal epidemiology, 26, pp.3654. 